\title{
A imortalidade da alma em Platão
}

\author{
The immortality of the soul in Plato \\ La inmortalidad del alma en Platón
}

Recebido: 05/09/2021 | Revisado: 11/09/2021 | Aceito: 20/09/2021 | Publicado: 22/09/2021

\author{
Alessandra Honorato Benfica Franco \\ ORCID: https://orcid.org/0000-0002-7784-3749 \\ Universidade Estadual de Santa Cruz, Brasil \\ E-mail: alessandrafilosofiauesc@gmail.com
}

\begin{abstract}
Resumo
O Tema deste trabalho investiga os princípios filosóficos da A imortalidade da alma em Platão. A metodologia empregue, foi em pesquisa exploratória e bibliográfica sobre textos de livros e artigos efetivos acerca o tema. Expõem hipóteses acerca da alma imortal, e esclarece sua importância no pensamento filosófico. A convicção platônica é sem dúvidas a mais expressiva que efetivou-se sobre a essência tradicional do homem, e até o presente momento as reflexões existentes do homem na civilização demonstram contínuos aspectos platônicos. Os estudos sobre a antropologia platônica podem ser consideradas em síntese no qual fundamentam-se os pré-socráticos sobre a convivência do homem com o kósmos, sob os ensinamentos sofísticos de um ser de Paidéia dedicado à vida política, e ao espólio hegemônico de Sócrates do homem interior e da psyché. Diferentes pesquisadores consideram a ideia platônica do homem um retrocesso no rumo dos estudos da sociedade num momento ao qual os pensamentos Sofistas eram imprescindíveis de criatividade distintas e essenciais das ações do homem, quando pareciam ser limitadas pelas incumbências, de protótipos de perfeição da teoria das Ideias, e da equidade da ciência humana, onde são envolvidas pela dualidade da sômapsyché preservadas no Fédon. É fundamental não deixarmos de lado que as ideias platônicas obtiveram fortes ações factuais na ascensão da filosofia, e no desenvolvimento da cultura do homem europeu, na contínua sociedade.
\end{abstract}

Palavras-chave: Platão; Imortalidade; Alma; Sócrates; Fédon.

\begin{abstract}
The theme of this work investigates the philosophical principles of The immortality of the soul in Plato. The methodology used was exploratory and bibliographical research on texts from books and effective articles on the subject. They expose hypotheses about the immortal soul, and clarify its importance in philosophical thought. The Platonic conviction is without a doubt the most expressive effect on the traditional essence of man, and up to the present moment, the existing reflections of man in civilization demonstrate continuous Platonic aspects. Studies on Platonic anthropology can be considered in summary, in which the pre-Socratics are based on the coexistence of man with the kósmos, under the sophistic teachings of a being of paideia dedicated to political life, and to the hegemonic spoils of Socrates of the inner man and the psyche. Different researchers consider the Platonic idea of man a step backwards in the direction of studies of society at a time when Sophistic thoughts were essential to distinct and essential creativity of man's actions, when they seemed to be limited by the tasks, of prototypes of perfection of the theory of Ideas , and the equity of human science, where they are involved by the duality of the somapsyche preserved in the Phaedo. It is essential not to overlook the fact that Platonic ideas had strong factual actions in the rise of philosophy, and in the development of the culture of the European man, in the continuous society.
\end{abstract}

Keywords: Plato; Immortality; Soul; Socrates; Phaedo.

\section{Resumen}

El tema de este trabajo investiga los principios filosóficos de La inmortalidad del alma en Platón. La metodología utilizada fue la investigación exploratoria y bibliográfica de textos de libros y artículos efectivos sobre el tema. Exponen hipótesis sobre el alma inmortal y aclaran su importancia en el pensamiento filosófico. La convicción platónica es sin duda el efecto más expresivo sobre la esencia tradicional del hombre, y hasta el momento actual, los reflejos existentes del hombre en la civilización demuestran continuos aspectos platónicos. Se pueden considerar en resumen los estudios sobre antropología platónica, en los que los presocráticos se basan en la convivencia del hombre con el kósmos, bajo las enseñanzas sofistas de un ser de paideia dedicado a la vida política, y al botín hegemónico de Sócrates de la el hombre interior y la psique. Diferentes investigadores consideran la idea platónica del hombre como un paso atrás en la dirección de los estudios de la sociedad en un momento en que los pensamientos sofistas eran esenciales para la creatividad distinta y esencial de las acciones del hombre, cuando parecían estar limitadas por las tareas, de los prototipos de la perfección de la teoría de las Ideas, y la equidad de la ciencia humana, donde están involucradas por la dualidad de la somapsyche preservada en el Fedón. Es esencial no pasar por alto el hecho de que 
las ideas platónicas tuvieron fuertes acciones fácticas en el surgimiento de la filosofía y en el desarrollo de la cultura del hombre europeo, en la sociedad continua.

Palabras clave: Platón; Inmortalidad; Alma; Sócrates; Fedón.

\section{Introdução}

Este trabalho investiga os princípios filosóficos sob o tema A imortalidade da alma em Platão. Tem por objetivo pesquisar as concepções da A imortalidade da alma do Fédon por Platão. Os Recursos da metodologia utilizada serão em pesquisa bibliográfica em textos, livros e artigos do referido tema. Abordando a seguinte problematização: Por que é importante para o conhecimento filosófico refletirmos sobre imortalidade da alma de Platão?

Justifica-se a escolha do tema baseado em saber o porquê o homem insiste tanto em viver uma busca incansável de algo que justifique qualquer coisa a mais do mundo físico ou de alguma coisa extra físico, que permaneça após ao fim da vida humana. Mediante a busca incansável do homem querer saber sobre algo pós morte, a concepção platônica nos traz por base, alguns consolos racionais, imagéticos e fundamentais do esmiuçado entendimento filosófico, pois Platão, realmente acredita que o mundo era possuidor de dois firmamentos: o mundo das ideias e o mundo sensível.

De tal modo que àquele mundo seja mais sublime que este, pois a alma sendo a única que já reside no mundo das ideias muito antes de ter vivido no mundo sensível. Ou melhor, a alma já existia! Onde tal dualismo platônico sobre corpo e alma, sendo a alma ser extra físico, diferentemente do corpo que deteriora-se, pois é composto por matéria, posto isto, a alma é sem margem de dúvidas um tema muito importante para a virtude e pensamento do filósofo.

A argumentação da alma imortal justifica-se em comprovar sua existência, mas não existe propensão de sua racionalidade, e sim apenas evidencias da sua individualidade e singularidade, e que apenas a morte permuta sobre a vida e vice versa. O homem busca incessantemente por respostas pelo imperecível, trazendo para si conflitos permanentes sobre a existência não ter sentido algum, pois pensar que não existe nada após sua a morte, além do vazio seria efêmera, então é melhor acreditar que a alma é essência vital que movimenta-se e impulsiona o corpo, e coragem em ser supervivente e, dona de sua imortalidade, pois faz parte das dúvidas da humanidade a recusa do vazio.

Na totalidade a alma é essência que movimenta-se, e anima o corpo físico, portanto é princípio vital, é ser sobrevivente, logo define-se um ser imortal. Tal tema em suma ainda seja tão discutido por inúmeros filósofos, a hipótese que mais consolida-se em tese de que a dualidade platônica é corpo e alma, posto que corpo é matéria, então é passível de putrescência e transformação.

Precisamos buscar fundamentos, que inspirem, primeiramente, um acordo acerca da existência ou não de um princípio vital fundamental intrafísico denominado na alma que corporifiquem seu sopro divino de princípios, pois a alma é intangível, intrafísica, passível, inteligente e vencedora da morte, ou seja alma imortal. No diálogos do Fédon a imortalidade é reconhecida em equilíbrio platônico, e firma-se nos diálogos em que relatam à penalidade de Sócrates.

Narra-se sua última conversa com seus aprendizes, em que ele havia sido acusado em desvirtua-los, e a sua sentença foi a pena de morte, logo o que para Sócrates é vista como pena de vida, pois a alma sendo imortal lhe permitirá habitar, finalmente nas esferas celestiais puras e imutáveis. Na Cultura da tradição grega, os infratores condenados à morte deveriam tomar a cicuta, um tipo de veneno que aos poucos, paralisa todas as funções vitais do corpo até sua morte.

Em particular, esta apologia é descrita no Fédon em quatro diálogos, e nos outros são de Críton, Eutífron, estes três são referentes à condenação de Sócrates, e em como acontece seus últimos momentos de sua vida, e em como encontrava-se o mestre em sua última conversa com Cebes e Símias. O compreender desta existência una no Fédon decorre em diferentes níveis: Ao nível sensível, onde os sentidos são unicamente habilitados, e aprendem sobre o tangível, nalgum nível inferior, imutável desprovida de totalidade. 
E ao nível inteligível, de entendimento passível e sensível, de pensamento desdito em si mesmo, e possui propensões de compreensão daquilo que é verdadeiro. Mas, a este nível só ocorre se a alma alcançar aquilo que é real e não está passível em suceder-se, pois neste nível a alma é possuidora das coisas sapienciais sendo essência cândida, divina, passível e inteligente, possibilitando a passagem do sensível ao suprassensível, das aparências que recepcionamos pelos sentidos aos seres em si, conhecidos pela inteligência.

\section{Metodologia}

A metodologia prática deste trabalho, refere-se a um estudo de estrutura bibliográfica exploratória, descritiva e reflexiva sobre a temática A imortalidade da alma do Fédon de Platão, propondo alcançar os objetivos apresentados. Foram Utilizado das seguintes obras como referencial teórico: Manuel Garcia Morente (1930), Evilázio F. Borges Teixeira (1999), Platão (1972), Casertano (2016), Droz (1997), entre outros.

Este trabalho procura tornar-se mais vasto o conhecimento proposto com aspectos de cooperar para que algumas reflexões, questionamentos e esmeros sobre o tema sejam esclarecidos sistematicamente e relacionados na construção do conhecimento filosófico. "É graças ao conhecimento que são construídas ideias, conceitos e ideologias que buscam explicar, de modo racional, diversas questões sobre o mundo e a vida humana" (Pereira \& et al, 2018 p, 16.). A pesquisa será elaborada por meio de leituras sistemáticas e produção de anotações, a partir de livros, artigos e fontes seguras da internet, que abordem o tema proposto.

E segundo Carlos Estrela (2018), é possível novas antecipações nas metodologias, onde durante seu desenvolvimento as etapas e os desafios na publicação tornando o resultado das referências indeclináveis às fontes metodológicas. A pesquisa bibliográfica em todo trabalho científico é um ciclo básico que inspira todos os ciclos de uma pesquisa, no momento em que a égide teórica em que se apresentará o trabalho, constituindo-se nesta procura a melhor escolha das leituras, anotações e organizações de dados referentes à pesquisa.

O objetivo desse livro não é dar conceitos simplificados sobre ciência, métodos, leis, teorias e processos de investigação. O seu objetivo é conduzir a um questionamento. Seu objetivo não é o de se transformar em um manual, mas o de ser um roteiro que desperte para a reflexão e crítica dos temas propostos e para a leitura e análise da bibliografia complementar (Koche, 2011 p, 18).

Nesta esfera englobam-se consubstancialmente pesquisas exploratórias e descritivas no que dizem respeito as ideologias e ou estudos pormenorizados de cada parte de um todo, para um melhor conhecimento de sua natureza, visto de vários lados do problema. Foi estabelecido no decorrer desta pesquisa um referencial teórico fundamentado em Platão e autores que objetivam desenvolver elementos teóricos conceituais, retirados de pesquisas bibliográficas que acabou contribuindo e constituindo a revisão desta literatura.

\section{Desenvolvimento}

A temática presente na fundamentação acerca da alma ser imortal, incessantemente foi início de muitas discussões, e atravessa a sequência cronológica por muitos pensadores inclusive antes mesmo de Platão. Discussões estas, que vivenciamos até o presente momento, pois a alma ainda é considerada uma incógnita para humanidade, mesmo que no período da Antiguidade tanto Platão quanto Aristóteles deram importantes contribuições para a incógnita em torno do ser humano. Ainda é possível vermos perguntas frequentes sobre se alma de fato existe? Sendo ela considerada um Ser, poderia sobreviver a morte e sua putrefação? E se reconhecida, a alma poderia realmente ser independente da matéria? Poderia uma alma sem um corpo (físico/matéria) e racionalidade, simplesmente ser um espírito que daria inteligência a esta matéria? 
Estas são apenas uma das inúmeras questões que nos permite divagar acerca dos diversos debates sobre sua imortalidade. Todavia, alguns materialistas reconhecem o princípio vital/alma como empírico, e cientificamente é impossível ao homem composto por corpo/alma sobreviver uma sem a outra, por cúmulo a alma é imperecível, infindável, infinita, interminável, perpétua, logo imortal.

Dizem eles pois que a alma do homem é imortal, e que hora chega ao fim e eis aí o que se chama morrer, e ora nasce de novo, mas que ela não é jamais aniquilada. É preciso pois, por causa disso, viver de maneira mais pia possível. [...] Sendo então a alma imortal e tendo nascido muitas vezes, e tendo visto tanto as coisas "que estão" aqui e quanto as "que estão" no Hades, enfim todas as coisas, não há o que não tenha aprendido; de modo que não é nada de admirar, tanto com respeito à virtude quanto aos demais, ser possível a ela rememorar aquelas coisas justamente que já antes conhecia. (Platão, 2015 p,45-47).

Então ficaria impossível chegarmos a um nível máximo de conhecimento, sem que tivéssemos acesso a alma, mas só depois de mortos, onde uma alma estaria recolhida intrinsecamente separada da matéria, e nunca antes disso. Isto é, só depois de mortos, e nunca enquanto vivermos. Para Platão, o ser humano é essencialmente alma, que é imortal e existe previamente ao corpo. Reflexões sobre sua subsistência ou não, sempre causaram polêmicas aos ocidentais não muito diferentes dos pensamentos gregos que tinham de "Apolo" como o seu Deus.

Todavia, alguns prognósticos de sua imortalidade não podem ser negadas, visto que tais evidências são discutidas na teoria da reminiscência, e similarmente pela teoria das ideias inatas. "Se a ciência é reminiscência, explica Cebes, desse fato decorre, necessariamente, que a alma preexiste ao corpo. Extensas explicações são dadas a Símias, que pedia provas. O raciocínio, rico e rigoroso, merecia uma análise detalhada, mas é claro que, aqui, estamos, incontestavelmente, fora do domínio do mito" (Droz, 1997 p, 64).

Ou então como explicaríamos as aptidões em determinadas pessoas a quem nunca tiveram convívio ou experiência e ou habilidade a música e artes? Segundo o pensador e filósofo Platão no Íon feito um elogio a arte, pois é provocada pelos deuses, não que a arte tenha excelência do conhecimento, que só é possível no mundo das Ideias; no entanto, ela possui sua validade como possibilidade de um saber dentro do mundo sensível.

Segundo ele a arte expressaria uma beleza capaz de ser alcançada também no mundo das sombras, demonstrando que o mundo das sombras não é todo o caos, mas que nele pode ser vislumbrada alguma verdade. A alma poderia ser vista como uma arte, e estaria também a disposição da educação, entendendo-a como um processo contínuo, e interrupto, como um eterno vir-a-ser. É posto que mediante ao tema avistamos um problema enigmático que ainda para muitos estudiosos torna-se distante em ser aceito nas Academias, e que a ciência não tem por propósito estudar a fundo.

Todavia este assunto é de puro interesse ao conhecimento filosófico nas áreas de estudo cientifico-filosófico (a exemplo: a filosofia da ciência), que demandam argumentar possíveis soluções e propostas conclusivas sobre a verdade de forma coesa na problemática da subsistência da alma imortal. Neste estudo vamos usar como parâmetro de referência Platão, em sua narrativa teórica a relação que o Mestre Sócrates tinha com seus aprendizes, e desta aproximação foi acusado de persuadi-los por terem relacionamento mais próximo com Sócrates, sendo condenado por degenerar a juventude e apresentar a eles novos deuses para a cidade grega, condicionando-os a terem pensamentos diferentes da doutrina tradicional.

Porém na narrativa Platônica, e as imposições postas não foram obstáculos para escrever as reflexões acerca das teorias socráticas. No seu arranjo Platão descreve Sócrates como tema principal, Platão é autocrático, e mestre influente principalmente nas suas primeiras escritas no início do desenvolvimento literário, denominadas como Período Socrático.

Se pensarmos na outrora Grécia até hodiernamente, ainda perdura-se os desafios na procura por respostas frente às investigações no que diz respeito se é real ou não a limitação da alma do homem em matéria, e a sempiternidade do 
macrocosmo da alma extra corpórea do homem, apresentado no diálogo do Fédon de Platão por volta de 335/388 aC, fundamentava-se neste diálogo o episódio do dia da morte de Sócrates, num sentido misterioso.

Mas a purificação não é, de fato, justamente o que diz uma antiga tradição? Não é apartar o mais possível a alma do corpo, habituá-la e evita-lo, a concentrar-se sobre si mesma por um refluxo vindo de todos os pontos do corpo, a viver tanto quanto puder, seja nas circunstancias atuais, seja nas quais se lhes seguirão, isolada e por si mesma, inteiramente desligada do corpo e como se houvesse desatado os laços que a ele a prendiam? [...] - Ter uma alma desligada e posta à parte do corpo, não é esse o sentido exato da palavra "morte"? (Platão, 1972 p, 75).

Temos como conhecimento seu maior alusivo, o Fédon, onde a concepção de perpetuidade da alma, transversalmente do diálogo do personagem Sócrates, Platão estabele-se na maiêutica socrática, visto que sua compreensão sobre a alma imortal. Já é possível encontrarmos os fundamentos em outras obras: Menon e Fedro, de mesma autoria, trazendo algumas comprovações sobre sua elucidação filosófica à perpetuidade da alma. As investigações serão feitas no Fédon, sendo esta uma obra inteiramente dedicada a imortalidade da alma, pois Fédon é considerado de suma importância para a ideia platônica de que uma alma estaria relacionada ao mundo das ideias, não ficando presas como correntes contínuas do mundo material que fixam-se na putrefação do corpo.

Referente ao advento do pensamento sobre a perpetuidade da alma, a dúvida nasce na procedência da sabedoria grega reconhecida principalmente pelos filósofos Platão e Sócrates. Embora Platão não tenha sido o introdutório em articular os princípios da perpetuidade da alma, foi ele quem da forma mais vigorosa trouxe ao tema um sentido a imortalidade. Para isto vamos recordar a proeminência de que a alma conserva-se como mutável e temporal, reconhecida pelo diferencial platônico entre ideias e coisa, uma vez que a coisa inclina-se facilmente ao delírio, já as ideia é pertencente a outro mundo, o das coisas essenciais, sublimes e eternas, a perfeição da verdade intrínseca além das ênfases sensíveis do mundo das ideias. "Se o mundo sensível não passa de cópia grosseira do mundo inelegível, se a única realidade verdadeira está do lado das ideias, o homem, este, é habitante dos dois mundos" (Droz,1997 p, 81).

\subsection{O mundo dos opostos acerca das cópias imperfeitas, e o mito de Andrógino}

É posto que Platão concerne que as coisas do mundo material, não passavam de cópias imperfeitas do mundo real, mas entende-se que entre elas há conexão das coisas e das ideias, uma arte imita a outra, e que remetem-se ao mundo das ideias "Para Platão, o ser humano é essencialmente alma, que é imortal e existe previamente a o corpo. A união da alma com o corpo é ocidental, pois o lugar próprio da alma não é o mundo sensível, e sim o mundo inteligível” (Nobrega \& et als., 2021 p, 04).

Segundo Platão, sua crítica da ideia de mundo e de verdade, defende que este mundo ao qual vivemos é o reflexo tênue de um mundo ao qual não vivemos, e que é a morada da verdade absoluta, ou seja, são dois mundos. "As almas humana, antes de viverem neste mundo e de alojar-se cada uma delas num corpo de homem, viveram em outro mundo, viveram no mundo onde não há homens, nem coisas sólidas, nem cores, nem odores, nem nada que passe e mude, nem nada que flua no tempo e no espaço. Viveram num mundo de puras essências intelectuais, no mundo das ideias (Morente, 1930 p. 39).

Os dois mundos estão vigentes no homem, sendo a alma conexa ao mundo das ideias, fazendo parte do mundo contínuo e extraordinária das ideias, e o corpo conexo ao mundo das coisas, de natureza corpórea ou incorpórea, e manifesta-se inconclusa de uma ideia. É em face à alma que o homem favorece-se, de forma eminente e mais demasiada ao mundo das ideias, mediante a alma humana, o homem teria idealizado suas concepções de preexistir, em virtude da alma inalterável e imortal precedente ao corpo, e depois que reencarnada perde sua conexão com o mundo das ideias.

Todavia é cognoscível com as coisas e imita-as e vai relembrando-se daquilo que já foi vivido, um saber, a Reminiscência/Anamnese, um conhecimento antecedente das ideias. É importante separarmos as indagações entre a alma e o 
corpo, pois ambas devem ser discutidas individualmente, posto que exercem parte de dois mundos heterogêneos, mas o homem ao estuda-las precisa diferencia-las. Mas em quais aspectos?

O envolvimento da anamnese na cognição apresenta duas vantagens e uma justificação. Esta última prende-se com a crítica, constante e contínua nestes diálogos, do reducionismo empirístico dos filósofos. As vantagens serão explicar o encadeamento das noções inteligíveis na alma, possibilitando uma investigação gradual, que como num sonho produz um estado cognitivo novo, ou o acesso a um outro "anterior", metacognitivo. Para além da analogia sugestiva com a recordação, encontramo-nos perante a viabilização do habitual método de pergunta e resposta (Santos, 2006 p, 536).

Tais aspectos destes dois mundos no diálogo, Fédon a diferenciação é vista de forma bastante negativa, considerando a alma aprisionada ao corpo e aos sentidos, e o corpo restrita a alma, "[...] se pelo contrário se separa do corpo impura, o que significa, pensando que nada é mais verdadeiro do que o corpóreo e fugindo do inteligível, oprimida pelo peso do corpo, por assim dizer, vagueia como sombra e imagem pelos sepulcros e, por isso, pode ainda ser vista" (Casertano, 2016 p, 147).

Ou melhor, só o verdadeiro filósofo, ocupação de quem filosofa retamente, é quem deseja a morte para libertar-se do corpo, pois seguindo o raciocínio, agiria, e em consequente chegaria a conclusão de que alma manteve-se pura, e parte para um lugar puro, nobre e invisível. "[...] sobre a purificação realizada pela filosofia, concluindo que, com esse tipo de vida, o filósofo não deve temer que a sua alma, ao separar -se do corpo, se dispersa e desapareça” (Casertano, 2016 p, 149).

Concerne a crítica da alma imortal uma das teses mais polemizadas na obra Fédon, e quais seriam as condições que portou-se Platão pensar acerca da alma? É sabido que o filósofo e grego Platão foi discípulo de Sócrates, e fez questão em descrever a morte de seu Mestre na obra Fédon.

O que aqui interessa a Platão, na argumentação dramática e dialógica intensa que se desenrola entre Sócrates e o seu interlocutor, é a conclusão deste procedimento: o corpo dissolve -se, a alma vai para o Hades. Nesta conclusão convém assinalar algumas "estranhezas" e algumas "reservas" que também aparecem, tais como aquela relativa imortalidade do corpo (quando morremos jovens e em boas condições, ou como quando o cadáver é embalsamado à maneira dos Egípcios), ou aquelas partes do corpo, como os ossos e os nervos, que se mostram «por assim dizer imortais; ou ainda, como a observação de que é muito mais provável que as coisas estejam assim, isto é, que a alma não pereça com a morte do corpo, porque a alma é totalmente indissolúvel, ou quase (Casertano, 2016 p, 146-147).

Pode-se considerar o Fédon uma belíssima obra que representa a doutrina de dois louváveis filósofos gregos fluentes no assunto da imortalidade. Podemos citar duas passagens muitos importante no Fédon, a primeira meditação seria a passagem em que Sócrates voltado sobre si mesmo argumenta sobre o próprio pensamento cuja a vida é o contrário da morte, no ato de seu conhecimento descreve que mesmo ocorreria com a privação do sono em oposto ao mesmo, sendo uma decorrente da outra. "Acaso "viver" não possui um contrário, assim como "estar acordado" tem por contrário "estar dormindo"? (Platão, $1972 \mathrm{p}, 80)$.

Como exemplo Sócrates tenta explicar que irá estar dormindo, do outro, estará acordado, em seguida, é de estar dormindo que provém de estar acordado, e de estar acordado que provém de estar dormindo, enfim, para estes dois termos, as gerações são, uma, adormecer, e outra, acordar. "A alma do morto, separada para sempre do corpo, estava em definitivo excluída de seu domicílio e da vida de seus descendentes, não havendo, portanto, nada mais a temer nem a esperar da psiqué do falecido" (Brandão 1991 p, 120).

A segunda passagem da meditação Sócrates "minha esperança de chegar a conhecer os seres começava a esvair-se. Pareceu que deveria acautelar-me, a fim de não vir a ter a mesma sorte daqueles que observam e estudam um eclipse do sol" (Platão, 1972 p, 112). Após dialogar a respeito dos próximos descendentes e sobre os seres subordinados, diz recear que tais indagações possam desalentar sua alma, da mesma maneira que tornar-se-ia cego por estudar eclipses observando-as 
diretamente o sol, sem tomar o cuidado em olhá-lo refletido. "Algumas pessoas que assim fazem estragam os olhos por não tomarem a precaução de observar a imagem do sol refletida na água ou em matéria semelhante" (Platão, 1972 p, 112).

Tais passagens ajustam-se para Platão assim como no mito de Andrógino, onde os paradigmas são restritas ao homem, que fora dividido ao meio. "Eu, vou, agora, disse, cortar pela metade cada um deles. Assim eles ficarão mais fracos, e ao mesmo tempo, render-nos-ão mais, já que seu número terá aumentado" (Droz, 1997 p, 30). Desta maneira, o homem sempre estará incompleto, aprisionado ao mundo dos opostos, onde viver é sondar a morte; e conjuntamente estariam limitados, e seus sentidos reduzidos a abrangência da sua sapiência.

Então quando o ser primitivo foi desdobrado em dois por esse corte, cada um com saudades de sua metade, tentava juntar-se novamente a ela. Abraçando-se enlaçando-se um ao outro, desejando formar um único ser, morriam de fome e de inanição, porque não queriam fazer nada um sem o outro. E, quando uma das metades morria a outra sobrevivia a ela, a metade sobrevivente procurava uma outra e a ela se enlaçava (Droz, 1997 p, 31).

Tanto a vida quanto a morte são supressórias, assim como as metades separadas que buscam reunir-se, e narram o mesmo ser, afirmando-se na morte como sendo o antagonismo da vida, e onde um está o outro também encontra-se. No Fédon, Sócrates explica a Cebes sua filosofia sobre a imortalidade da alma: "tenho muita esperança de, por esse modo, explicar-te a causa e chegar a provar que a alma é imortal" (Platão, 1972 p, 113). E Sócrates continua a explicar sobre a ideologia dos opostos, mas com a dúvida a respeito da vida e da morte, onde viver seria o oposto, de estar morto?

Logicamente, deveriam significar, em primeiro lugar, uma não identidade: a alma não é o invisível, mas é semelhante ao invisível, o corpo não o visível, mas é semelhante ao visível; e em segundo lugar, uma relatividade: em relação ao corpo a alma é mais semelhante ao invisível, em relação à alma o corpo é mais semelhante ao visível. Mas isto implicaria, logicamente, uma certa visibilidade da alma, claramente inferior à do corpo, e uma certa invisibilidade do corpo, certamente inferior à da alma. (Casertano, 2016 p, 146).

Inicia-se neste momento contínuas dúvidas e respostas que acabam na hipótese de que os vivos não corroboram menos mortos e tampouco dos mortos com os vivos, e estas seriam para ele uma prova razoável de que as almas dos mortos estariam em alguma parte, e que é de lá que elas voltariam para a vida.

Após a enunciação daquilo que parece ser uma lei geral dos acontecimentos, isto é, a que se refere ao nascimento a

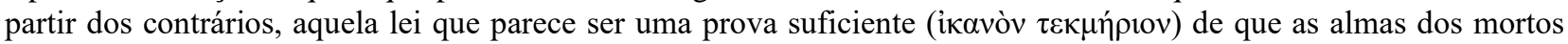
estão necessariamente em algum lugar e de lá voltam a nascer outra vez; após ter sido desenvolvido o argumento da aprendizagem como reminiscência, em que, mais uma vez, o aspecto mais propriamente epistémico acaba por misturar-se com o mítico da pré -existência das almas e, por conseguinte, da sua imortalidade, demonstração mais uma vez declarada "suficiente" após Símias e Cebes terem realçado que a demonstração de Sócrates, de facto, só provou, por assim dizer, meia imortalidade, porque demonstrou apenas que a alma pré -existe ao nosso nascimento, mas não que continuará a existir também depois da nossa morte (Casertano, 2016 p, 144).

\subsubsection{O Homem a sua própria Reminiscência}

A próxima alegação de Sócrates é a Reminiscência, neste argumento, Sócrates descreve que o conhecimento do homem não é outra coisa, e sim a própria Reminiscência, onde aprende-se que períodos anteriores são exatamente àquilo que hodiernamente recordam-se. Mas não seria possível a este fenômeno se a alma não se encontrasse em um lugar escolhido antes de tomar-se descendente da condição humana. Alcançou antes do advento a sapiência do Belo, do Bom, do Santo em si, etc., ou mesmo antes de seu surgimento o princípio vital já teria apreciado as formas mais artísticas do mundo inteligível.

O aprender compreende em retomar a sapiência que já retida é rememorar-se o conhecimento do indivíduo, é a própria Reminiscência! Aprender, nada mais é do que recordar-se. "Por conseguinte, ainda por esta razão é verossímil que a 
alma seja imortal” (Platão, 1972 p, 82). É posto que não existam dúvida de que numa vida anterior, podemos ter aprendido fatos de que hodiernamente nos recordamos. "Ora, tal não poderia acontecer se nossa alma não existisse em algum lugar antes de assumir pela geração, a forma humana" (Platão, 1972 p, 82).

O pensamento sensível dos artefatos materiais fomenta a alma para a Reminiscência das coisas admiráveis do mundo inteligível, e seria o mesmo que o homem ou almas estabelece-se relação com o aspecto da natureza gradativa uma longínqua, lembrança de tornar-se perceptível ao íntimo de sua alma. A alma advir por uma rememoração das coisas já vistas em sua verdadeira morada, do que constata-se no mundo dos sentidos, são somente reflexos da exatidão do mundo das ideias. Sócrates pressupõe estes fenômenos, como todos de mundo simples, imagem das formas eternas. "A união da alma com o corpo é acidental, pois o lugar próprio da alma não é o mundo sensível, e sim o mundo inteligível" (Cotrim, \& Fernandes, 2010 p, 23).

Desta confirmação no Fédon: ser a alma um ente imortal, é que dá a Sócrates conforto no momento da morte. "Isso requer sem dúvida uma justificação, a qual provavelmente não há de ser coisa fácil, para fazer crer que depois da morte do homem a alma subsiste com uma atividade real e com capacidade de pensar" (Platão, 1972 p,78).

O que Platão pretendia apresentar em seus diálogos é sua filosofia platônica, onde ele repete por vários momentos sobre a absoluta verdade não ser uma posse humana, apenas divina. Platão constrói o discurso "belo" ser sempre um bem, por que só com os discursos (belo e bom) se constrói um sentido para a vida boa e justa. No Fédon, Sócrates no momento de sua morte, sendo a alma tudo aquilo que existe, portanto imortal, busca conforto braceado pela logos, prevendo uma chance da bem aventurada existência na pós vida. Mas Sócrates deixa claro que a esta possibilidade só é possível a alma, pois quem na pós morte persistiu a vereda da virtude e da benevolência, e segundo ele nada mais é que pôr em prática a filosofia, buscando a alma para si mesma a máxima apreciação da Virtude em si.

\subsubsection{As discussões sobre a Filosofia do filósofo Sócrates}

Segundo Teixeira, a máxima sabedoria somente é alcançada depois da morte, já que na companhia do corpo, não é possível obter conhecimento puro do que quer que seja. "Porque a alma é evidentemente imortal. Eis uma opinião que me parece boa e digna de confiança. Belo é ter esta coragem" (Teixeira, 1999 p, 88).

O filósofo de todos os mortais, é aquele que mais se aproximou da verdade e da sabedoria. Ele não tem medo da morte, pelo contrário, o filósofo é aquele que dedicou-se a vida para filosofia e na hora da morte mostra-se confiante e esperançoso de poder participar dos mais valiosos bens. É possível a todos dedicarem-se verdadeiramente a filosofia e nada mais aspirem do que a morrer e estarem mortos. Ele não tem medo da morte, pelo contrário, o filósofo é aquele que dedicou-se a vida para filosofia e na hora da morte mostra-se confiante e esperançoso de poder participar dos mais valiosos bens. É possível a todos dedicarem-se verdadeiramente a filosofia e nada mais aspirem do que a morrer e estarem mortos.

Na filosofia de Platão, não se pode falar realmente de três faculdades da alma. Seria mais apropriado utilizar o termo parte no lugar de função ou faculdade. Com efeito, Platão, para deixar mais claro que cada uma das partes realiza uma função própria que não pode ser confundida com a função de outra parte da alma, coloca as três partes da alma em diferentes posições no interior do corpo humano (Botter, 2016 p, 38).

No Fédon, Platão descreve uma doutrina para entendimentos dos termos filosóficos para explicar melhor a concepção sob o dualismo puritano, que demonstra uma escrupulosa pureza moral, austero e rígido respeito pelos princípios e zela pelos costumes, onde em primeira perspectiva a alma atribuiria todos os pecados e sofrimentos a poluição quando coabita-se ao corpo/matéria, surge a clássica da morte pela autodisciplina em que o eu racional purga-se das loucuras de seu próprio corpo e recupera-se por sua verdadeira índole, visto que assim a alma divina e sem pecado, a boa vida será desta prática, desta meletê thanátou, a purificação. 
Cogitando que a morte seja o antagonismo da vida entende-se a certeza de outrora definida, a alma tem como indício fundamental a vida não podendo abrigar-se intrinsicamente a morte será imortal. A aurora dos opostos que omite-se não vem reconhecer a subsistência da alma racional minuciosa e particular; para demonstrar sua circunstância a razão carece conceder com intuito de aperfeiçoamento a Teoria da Reminiscência, e para tal rememora-se de suas maiores faculdades.

[...] Desde, que, vendo uma coisa, a visão desta faz com que penses numa outra, desde então, quer haja semelhança ou dessemelhança, necessariamente o que se produz é uma recordação? [...] passam-se as coisas para nós a forma como as igualdades dos pedaços, de pau e como as de que falávamos há pouco? Essas coisas nos parecem iguais assim como o que é Igual em Si? Falta-lhes ou não lhes falta algo para poderem convir ao Igual? (Platão, 1972 p, 84).

As premissas dos opostos que não se incluem, só nos confirma a condição da metamorfose das percepções, ou acatam-se com a razão. As faculdades adjacentes das premissas no Fédon é que equilibram a dúvida da alma não ser mortal, e que esta profetiza e antecedem o corpo, não sendo dizimada com este, e nem somente advém a cada incorporação de espírito em corpo, mas contrapõem-se por todo, as fases como ser inigualável e particular.

As perguntas bem feitas, o esforço por dirigir a intuição para a essência do objeto proposta gradativamente, e não de chofres com uma série de flechadas sucessivas, encaminhando o esforço do espírito para onde deve ir, conduzirão a Reminiscência, a recordação daquelas ideias intelectuais que as almas conheceram e que logo irão encarnar-se em corpos humanos, sobreviverão a passagem para a morte. A arguição dos opostos consta no diálogo ditas ao esclarecimento da Reminiscência, como integrante e imanente, isto é, a ideia dos opostos, e a teoria da Reminiscência, dão existência intermediaria do mesmo resultado em que da imortalidade da alma mantem-se em si, o logos - fatos que serão rememorados por Sócrates.

Ao compararmos os diálogos de Fédon Menon e Fedro, podemos ter uma concepção da dependência no que refere-se ao fundamento do rememorar e do desenvolvimento da aprendizagem do conhecimento. Pois Platão tinha a concepção de que o lembrar nada mais é do que reconhecer, aquilo que já tinha sido visto, e que estava guardado no esquecimento de nossa alma.

Desta afirmação conclui-se, que as percepções de raciocínio defendidas por Platão em que a sapiência não seria como um objeto a ser obtido de qualquer forma, e nem desenvolveriam capacidades a partir do nada, e sim numa metodologia educacional em concordância daquilo que já subsiste estava escondido, sendo a vida um percurso contínuo para o relembrar.

Neste diálogo, a morte recebe muitas definições ou caracterizações: morte como separação da alma do corpo, sentido metafórico da morte, e dissolução total do ser humano (alma e corpo), que constitui precisamente a origem do medo da morte. Mas é sobremaneira importante a morte vista em sentido metafórico. Neste sentido, aquilo que num primeiro momento fora pensado simplesmente como "separação" da alma do corpo adquire uma conotação especial, conotação que, a meu ver, se enquadra num horizonte especificamente gnosiológico. Este horizonte é reafirmado no que Sócrates chama a opinião que os filósofos genuínos devem continuamente repetir a si mesmos, e que é o trilho que os conduz na investigação, precisamente com o raciocínio: enquanto a alma estiver unida ao corpo, na busca da verdade, não poderemos conhecer nada na sua pureza. Adquire -se o saber, portanto, só quando morremos, o que significa, no significado metafórico do termo morte, quando a alma investiga sozinha a verdade sem o envolvimento da sensibilidade. Que é uma perspectiva absolutamente não metafísica, porque é precisamente a mesma perspectiva também do "materialista" Demócrito, quando afirma que o conhecimento $(\gamma v \tilde{\omega} \mu \eta)$ que nos deriva dos cinco sentidos é obscuro ( $\sigma \kappa \circ \tau i ́ \eta)$, enquanto que o outro conhecimento, bem distinto deste, superior a ele, e que visa a verdade, isto é, o conhecimento genuíno ( $\gamma v \eta \sigma i ́ \eta)$, se adquire só com o ato de pensar ( $v \tilde{\omega} \sigma \alpha l)$ e com o intelecto. Isto é o que Platão chama, comum termo retirado da tradição dos mistérios e por ele elevado a valor gnosiológico e ético, "purificação" do filósofo, ocupação de quem filosofa retamente (Casertano, 1996 p, 142-143).

O Fédon é uma das obras mais conhecida de Platão, e Fédon é um jovem aristocrático que desde muito cedo dedicouse plenamente a filosofia e transmudou-se como aprendiz de Platão. Neste diálogo, Fédon narra a última conversa de Sócrates, 
claramente erguida pelo filósofo grego, e tinha como temática, fundamental - a imortalidade da alma. E o que intercorre com o princípio vital pós morte?

\subsection{O problema da educação, a concepção da Alma Imortal}

À vista disso, a filosofia platônica primeiramente explana sua compreensão sobre o desejo do filósofo que é morrer, em razão de sua filosofia estabelece-se num educar-se à morrer e vivenciar a morte. As indagações outorgam a sapiência e presumem a égide o princípio vital por si só, ação símil ao da decomposição entre corpulência, e princípio vital decorrente do falecimento.

No Fédon, as explanações podem ser explicativas quando apresentadas por Sócrates em concordância da cicuta, sua concepção de imortalidade lhe serve de respaldo para sua aceitação, desde que respeitem e obedeçam as leis, e Sócrates poderá escarnecer posterior a morte a equivalência dos afortunados. "No Menon dizem de fato que a alma do homem é imortal, e que as vezes se chega ao fim, o que chamam morte, as vezes ressurge novamente, mas nunca é destruída: justamente por isso é preciso transcorrer a vida da maneira mais sensata possível” (Zilles, 2019 p, 606).

À vista disso, a hipótese de outrossim a imortalidade torna-se permanente, a alma é indelével impossível de ser indestrutível, enquanto que a morte aproxima-se, pois a alma jamais aceitará a morte e tão pouco ficará morta.

Os proventos do que pensamos, a alma sequer concordará a morte e nem ao menos ficará morta de natureza igual como apoiado nos nossos antecedentes, assim como "nem o três será par, nem o ímpar será par, nem o fogo será frio, nem o calor no fogo será frio, e assim por diante" (Platão, 1972 p, 119-120).

Concluindo Sócrates, de forma precisa concerne-se entre a consumação do compromisso moral a crítica ética da servidão, e gratificação devida no horizonte pós-morte, dado isso seu inalterável acatamento da cicuta. É na resposta de Sócrates a Críton que determinou-se por fim tal conexão, e Críton que questionou-lhe o que teria que engendra seu corpo após objetiva morte, e consequentemente Sócrates disse aos seus discípulos que ficaria entre eles; porém em afirmativa que não ficaria entre eles quando morresse.

Seria este o singular método que engendra tal martírio tenha sido o mais admitido por Críton, o modo em não abalarse e frustrar-se quando observaria o corpo de Sócrates "meus amigos de convencer Críton de que o que sou é este Sócrates que se acha presentemente conversando convosco e que regula a ordem de cada um de seus argumentos" (Platão, 1972 p, 129), e pensasse de fato que estaria vivenciando angústias, e que ao longo do sepultamento dizei-a que estaria expondo Sócrates, carregando-o ao sepulcro e velando-o. "Muito ao contrário, está persuadido de que sou aquele outro Sócrates cujo cadáver estará daqui a pouco diante de seus olhos; ei-lo a perguntar como deve me enterrar" ! (Platão, 1972 p, 129).

Todavia, podemos compreender que Platão tenta provar no diálogo que a alma transformar-se em ser perpétuo, e possuidor de sapiência, e mudança. "Que depois de tomar o veneno não estarei mais junto de vós, mas me encaminharei para a felicidade que deve ser dos bem-aventurados (Platão, 1972 p, 129). Podemos ler tanto no Fédon quanto no Menon que a afirmação sobre a alma ser um elemento perpétuo, é o que daria a Sócrates alento no ápice da morte em razão de ficar acenado pelo logos, de haveres uma presença afortunada na pós vida, pois já nos é sabido que Sócrates viveu a serviço da virtude e da Bondade, da Virtude em Si, a serviço da prática a filosofia.

Mas a que propostas digo essas coisas? A propósito das opiniões que são verdadeiras. Pois também as opiniões verdadeiras, por tanto tempo quanto permaneçam, são uma bela coisa e produzem todos os bens. Só que não se dispõem a ficar muito tempo, mas fogem da alma do homem, de modo que não são de muito valor, até que alguém as encandeie por um cálculo de causa. E isso amigo Menon, é a reminiscência, como foi acordado entre nós nas coisas ditas anteriormente (Platão, 2015 p, 96-97). 
O esclarecimento deste trabalho resulta justificar a subsistência da alma imortal, mas não cabível de comprovação que a alma permaneceu racional, em outras palavras, se alma permanece imortal transforma-se inigualável e particular, conjecturase meramente que a morte permuta a vida e vice-versa. O argumento origina-se do ato contínuo de uma narrativa de modo prévio que guiou os sábios a prisão, o lugar que permanecia Sócrates, e aduz uma complexidade de indagações pertinentes as percepções da morte e as virtudes no pós morte.

Para Sócrates, o corpo é cárcere da alma, em virtude desta ser oposta a matéria, contudo é neste frondoso corpo que a alma habita, e obrigatoriamente no ensejo instante em que a alma este princípio vital solicita desprender-se.

E quem mais veementemente deseja desprender-se da alma são acima de qualquer um, e segundo Sócrates seriam os filósofos, pois estes são de maneira geral os que em vida alvitram o altruísmo das coisas do corpo, e desassociam-se das arrogâncias materiais. Mas só advém, logo que a alma desprendem-se, e se a alma destes pretendidos desprendem-se, logo aprendem, e por qual razão conseguem o supremo compreendimento.

\section{Considerações Finais}

O epílogo deste trabalho não ignora o entendimento da metafísica platônica, visto à aquele que manifesta seu desejo verossímil em compreender a filosofia que advém do estudo da cognição segundo o espólio de Platão. Mediante o Fédon ao ser retratado por Platão, constata-se que estamos mediantes a uma grande obra de perfeição literária filosófica.

Neste diálogo Platão deixa explícito por inteiro seu raciocínio dialético, e segundo ele o homem em equilíbrio era desprendido de corpo e alma, pois entendemos como corpo aquilo que abrange-se na matéria, e pôr a alma aquela que compõese no imaterial do mais sublime que o homem tenha usufruído. O corpo constantemente permanece em transformação de conceito e aspecto, e a alma nunca metamorfoseia-se, sob a condição hipotética de que o homem advém duma alma imaculável, mas sem embargo, não sabemos. "É claro que se há uma metafísica platônica, ela certamente tem nas Formas o seu foco de investigação, ou seja, tem como temática a possibilidade da existência das Formas como objetos de um tipo especial, um tipo que teria certas características, hierarquias e modos de ser distintos de outros objetos, especialmente dos objetos ditos sensíveis" (Nazareno, (2019 p, 179).

As veracidades fundamentais estão comprovadas no princípio vital perpétuo, contudo ao descender esquece-se, que o princípio vital é preso ao corpo. Platão conceitua que o princípio vital pós morte reencarna num outro corpo, mas a alma ligase com a concepção filosófica e com o Bem, e destina-se a perfeição do romper da morte e do corpo. A alma lhe é concedida o ensejo de percorrer o restante da sua existência coexistindo com as divindades (os deuses gregos), em razão da sapiência do princípio vital ser aquela que dá o intelecto à vida. Na totalidade, foi pronunciado pelo seu criador o Demiurgo, um inconcebível mestre que arquitetou o universo verossímil esclarecendo suas ideias e ou do pensamentos.

A ato dos homens limitam-se ao mundo material; como se simplesmente fosse alguma coisa material que os conduz, e no mundo das ideias o homem não pode transformar nada, uma vez que sendo imaginário não pode mais acompanha-lo pois trata-se somente de algo material. Por meio de Sócrates no Fédon Platão faz inferências em uma argumentação com propósito de conduzir os receptores a obedecerem como aceitável as inferências que assegura ser imortal a alma e continua sendo racional pós morte da dualidade corpo e alma. Não obstante Sócrates salienta a Teoria dos Contrários conduzindo o indício que os contrários não se incluem, entretanto a morte converte-se no oposto da vida.

O método encaminha-se do gerar-se ao falecer e detêm duas restrições próprias, a primeira: a vida que origina-se da morte, e a segunda: a morte que sobrevêm da vida. Quando pensamos no processo que se inicia ao nascer e o fim ao morrer, assimilamos a uma linha temporal que divide-se em dois: a primeira que dará origem na morte e a segunda da morte que dará origem a vida. Nestes dois momentos vida/morte vamos encontrar o tempo de viver, onde a alma este princípio vital maravilhoso e transcendental divide-se entre o corpo, este ser corrompível, e designado ao extermínio. 
Declarava Sócrates como prova que o compromisso do filósofo é refletir sobre a vida e morte como períodos opostos e supressivos, sendo praticada as conexões compreendendo como artefato do primeiro índice da imortalidade da alma, uma existência que preexiste, sobreleva-se e caminha ao viver. "Sim, e é o próprio filósofo quem nos assegura no Fedro, considerando-a, inclusive, uma predisposição divina perfeita pelo amor. É por essas e outras que, talvez, Wittgenstein nos diga que só quando se pensa mais loucamente do que os filósofos se consegue resolver os seus problemas" (Amaral, 2018 p,11).

O Fédon foi factualmente associado a comunidade dos Diálogos, onde sob várias coisas organizou a poesia, a literatura e a filosofia, e relacionou a temática da morte de Sócrates, permanecendo a razão, ainda que junto ao Eutífron, apologia de Sócrates e Críton, sendo agrupados na primeira quadrilogia, segundo a organização de Tasilio, pelo propósito coletivo que é imortalizar a memória proporcionando além disso, a proteção de Sócrates. "De acordo com a edição em tetralogias das obras de Platão feita pelo gramático latino Trásilo, no século I de nossa Era, edição mantida por Henri Ettiénne no século XVII e finalmente adotada por John Burnet quando da publicação da Universidade de Oxford, o Teeteto seria o segundo de quatro diálogos: seguir-se-ia ao Crátilo e antecederia O Sofista e O Político" (Aquino, 2019 p, 229).

Hodiernamente, é posto que o Fédon foi inscrito em torno de a 335/388 a.C., incluindo-se nos diálogos do período medieval juntamente com o Banquete, A República e Fedro, no ápice em que Platão tinha propiciado suas ideias filosóficas escrito após sua primeira viagem à Sicília, cuja finalidade da ida de dele, foi na ideia de aprender com a comunidade Pitagórica que residia lá em Siracusa. "Ela apresenta, sobretudo através do estudo da alma, a dívida de Platão para com os pitagóricos" (Watanabe, 1995 p, 400).

Encontram-se pessoas que embrandecem-se ao enxergarem que no Diálogo fundamenta-se a peripécia verdadeira sobre o dia da morte de Sócrates; e não enxergam a aristocracia do autor, sua coragem e poder de argumentação sabendo exatamente onde adaptar o propósito filosófico em proteger a Teoria das Formas, vis-à-vis do futuro, não pretendido, mas não ignoto de modo nenhum limita-se na própria morte.

O método de pensar exposto por Platão vai do surgimento do enigma a composição da dúvida acerca do que advém pós morte, e as precipitações em descobrir estas questões; estipulou-se a denominar recorrendo incessantemente ao logos, visto que, buscou em ostentar distanciar a ênfase das cresças e discriminação, inclusive seu marco final na ocasião em que ele refuta acerca da questão, sobre sua Teoria das Formas, e enfim afirma a sua hipótese.

\section{Referências}

Botter, B. (2016). Ética II. Universidade Federal do Espírito Santo, Secretaria de Ensino a Distância.

Casertano, L. (2016). Alma, morte e imortalidade. Archai, 17, 137 -157.

Droz, G. (1997). Os mitos platônicos. Editora Universidade de Brasília.

Estrela, C. (2018). Metodologia Científica: Ciência, Ensino, Pesquisa. Editora Artes Médicas.

Garcia, M. M. (1930) Fundamentos da Filosofia. Mestre Jou.

Koche, J. C. (2011). Fundamentos de metodologia científica. Vozes.

Pereira A. S. et al. (2018). Metodologia da pesquisa científica. UFSM.

Platão. (1972). Os Diálogos: O Banquete, Fédon, Sofista, Politico (Coleção Os Pensadores). Victor Civita.

Platão. (2015). Menon. Folha de S. Paulo.

Platão. (2018). A República de Platão. Perspectiva.

Teixeira, E, F, B. (1999). A educação do Homem Segundo Platão. Paulus.

Brandão, J.de S. (1991). Mitologia Grega. Vozes.

Santos. J. G. T. (2006). Linguagem e pensamento na filosofia grega clássica. Rev. Int. Fil. 29(2), 525-550. 
Research, Society and Development, v. 10, n. 12, e298101220258, 2021

(CC BY 4.0) | ISSN 2525-3409 | DOI: http://dx.doi.org/10.33448/rsd-v10i12.20258

Aquino. J, A. (2019). A aporia no Teeteto de Platão: por uma filosofia perene. Revista Helius, Sobral 2(2), 229-250.

Cotrim, G., \& Fernandes, M. (2010). Fundamentos da Filosofia. Saraiva.

Nóbrega, J. C. da S., Freitas, M. B. de S., Bezerra Neto, F. das C., Monteiro, A. de O. A. Araújo, B. S., \& Barbosa de Lima, L. T. (2021). Felicidade em Platão e Aristóteles. Pesquisa, Sociedade e Desenvolvimento, 10 (6).

Watanabe, L. A. (1995). Platão, por mitos e hipóteses: um convite à leitura dos diálogos. Moderna.

Amaral. F. F.S. (2018). Mas, afinal, para quê, então, filosofia? Uma leitura do Górgias de Platão. Editora UFFS.

Zilles, U. (2019). A Imortalidade da alma em Platão e Plotino. Veritas, 48(4), 603-612.

Nazareno. E. A. (2019). A metafísica platônica como método das formas. Dissertatio. 49, 175-245. 